\title{
Монацит — геотермометр Монтеля
}

Денисова Ю.В.

Институт геологии Коми НЦ УрО РАН, Сыктывкар, yulden777@yandex.ru

Аннотация. В работе представлены результаты использования монацита в качестве геотермометра по методу Дж. М. Монтеля. На основе термометрии насыщения по монациту были рассчитаны температуры образования гранитов Николайшорского массива (Приполярный Урал), которые согласно представленным результатам находятся в диапазоне от $708^{\circ} \mathrm{C}$ до $784^{\circ} \mathrm{C}$ и в среднем составляет $738^{\circ} \mathrm{C}$. Полученные данные были сопоставлены с температурами, выявленными ранее для циркона (метод Дж.- Р. Пюпена и Е.Б. Ватсона) и апатита (метод Е.Б. Ватсона).

Ключевые слова: монацит, гранит, Николайшорский массив, Приполярный Урал, геотермометр, Дж. М. Монтел.

\section{Monazite as a Montel geothermometer}

\section{Denisova Yu.V.}

Institute of geology of Komi SC UB Ras, Syktyvkar, yulden777@yandex.ru

\begin{abstract}
The paper presents the results of using monazite as a geothermometer by the J. M. Montel method. On the basis of monazite saturation thermometry, the temperatures of granite formation in the Nikolayshor massif (the Subpolar Urals) were calculated, which are in the range from $708^{\circ} \mathrm{C}$ to $784^{\circ} \mathrm{C}$ and averages $738^{\circ} \mathrm{C}$ according to the presented results. The obtained data were compared to the temperatures previously identified for zircon (J.- P. Pupin and E.B. Watson method) and apatite (E.B. Watson method).
\end{abstract}

Key words: monazite, granite, Nikolaishor massif, Subpolar Urals, geothermometer, J. M. Montel.

\section{введение}

В настоящее время все чаще используют акцессорные минералы в качестве природных геотермометров. Большинство работ по термометрии связано с цирконом, что объясняется разнообразием существующих методик: классическая эволюционно- кристалломорфологический анализ (Pupin et al., 1980), термометрия насыщения (Watson et al., 1983), термометр Ti-in-zircon (Watson et al., 2006). Однако, если термометрия насыщения Е.Б. Ватсона позволяет определять температурные режимы формирования различных пород, методика Дж.М. Монтеля (Montel, 1993), основанная так же на изучении породного уровня организации вещества, дает такую информацию только для гранитов.

Целью работы является определение температуры формирования гранитов Николайшорского массива с использованием термометрии насыщения Дж.М. Монтеля.

В юго-восточной части Приполярного Урала в бассейнах рр. Николай-Шор и Иг-Шор отмечается группа мелких изолированных тел гранитоидов, прорывающих гнейсы няртинского метаморфического комплекса раннепротерозойского возраста. Наиболее крупное из этих тел, длина которого составляет 4 км при средней ширине 1.5 км, получило название Николайшорского массива (рис. 1). Породы рассматриваемого массива, согласно А.М. Пыстину (Пыстин и др., 2008), определяются как плагиогранито- гнейсы и гранито- гнейсы. Причем гранито- гнейсы развиваются преимущественно за счет плагиогранито- гнейсов и пространственно тесно связаны с ними. По классификации Б. Чаппела (Chappeil, 1974) Николайшорский массив относится к S - типу.

Монацит в изученных гранитах встречается преимущественно в виде полупрозрачных округлых желтых и темно-желтых зерен, размер которых составляет 0.10-0.20 мм. Наиболее часто этот минерал отмечается в виде включений в биотите.

Методика Дж.М. Монтела, позволяет рассчитать температуру кристаллизации монацита, представляющего собой фосфат лантаноидов, и монацитсодержащей породы на основе экспериментально установленной зависимости между содержаниями LREE, основных элементов и $\mathrm{H}_{2} \mathrm{O}$ в расплаве и температурой: 


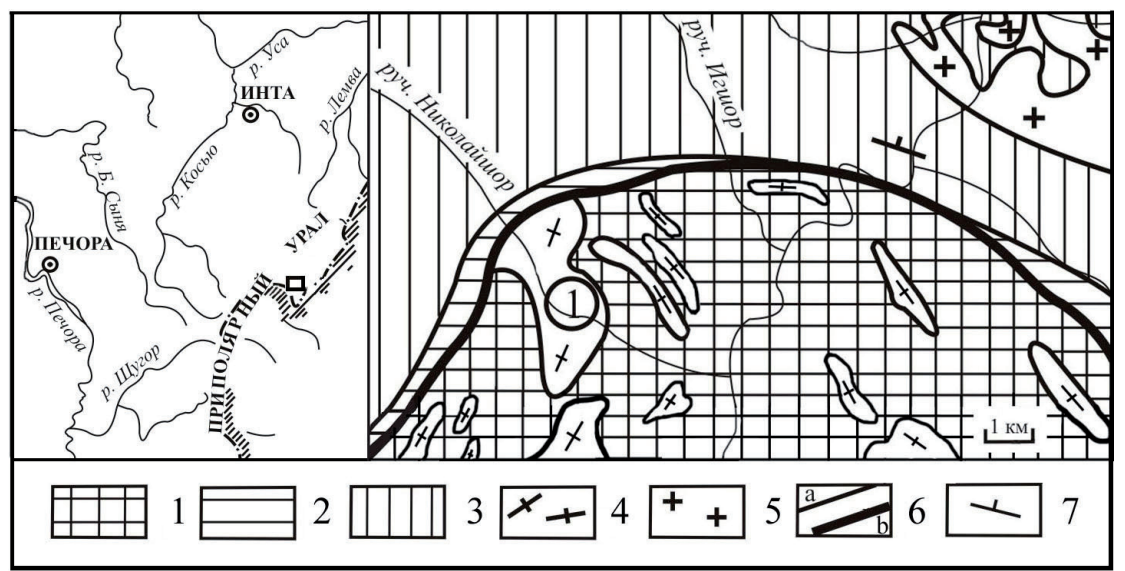

Рис. 1. Николайшорский гранитный массив (по А.М. Пыстину).

1 - биотитовые и двуслюдяные гнейсы с простоями амфиболитов; 2 - известковистые кристаллические сланцы, мраморы, кварциты, амфиболовые сланцы; 3 - слюдяно- кварцевые сланцы, зеленые ортосланцы, метапорфиры, кварциты; 4 - гранито-гнейсы; 5 - граниты; 6 - геологические границы: а - стратиграфические и магматические, $\mathrm{b}$ - тектонические; 7 - элементы залегания плоскостных структур. Массивы (цифры в кружочках): 1 - Николайшорский.

Fig. 1. The Nikolaihsor granite massif (after A. M. Pystin).

1 - biotite and two-mica gneisses with amphibolites layers; 2 - calcareous shales, marbles, quartzites, amphibole shales; 3 - mica-quartz shales, green orthoshales, metaporfyry, quartzites; 4 - granitoid gneisses; 5 - granites; 6-geological boundaries: a - stratigraphic and magmatic, b-tectonic; 7 -elements of occurrence of planar structures. Massifs (numerals in circles): 1 - the Nikolaihsor massif.

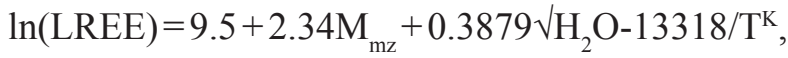

$$
\begin{aligned}
& \mathrm{LREE}=\left(\Sigma\left(\mathrm{REE}_{\mathrm{i}}\right) / \mathrm{REE}\right) / \mathrm{X}_{\mathrm{mz}} \text {, } \\
& \mathrm{M}_{\mathrm{mz}}=100(\mathrm{Na}+\mathrm{K}+\mathrm{Li}+2 \mathrm{Ca}) /(\mathrm{Al}(\mathrm{Al}+\mathrm{Si})),
\end{aligned}
$$

откуда

$$
\mathrm{T}^{\mathrm{C}}=13318 /\left(9.5+2.34 \mathrm{M}_{\mathrm{mz}}+0.3879 \sqrt{\mathrm{H} 2 \mathrm{O})}-\ln (\mathrm{LREE})\right)-273.15,
$$

где $\mathrm{REE}_{\mathrm{i}}$ - содержание $\mathrm{La}, \mathrm{Ce}, \mathrm{Pr}, \mathrm{Nd}, \mathrm{Sm}, \mathrm{Gd}$ в расплаве, атом. вес, REE - суммарное содержание LREE в расплаве, атом. вес, $\mathrm{X}_{\mathrm{mz}}$ - суммарное содержание LREE в расплаве, мол. вес, $\mathrm{M}_{\mathrm{mz}}-$ соотношение катионов, $\mathrm{H}_{2} \mathrm{O}$ - предполагаемое содержание воды в расплаве, $\mathrm{T}^{\mathrm{K}}$ - температура, Кельвин, $\mathrm{T}^{\mathrm{C}}$ - температура, Цельсий.

Для расчета температур насыщения для монацита были использованы данные химического состава гранитов Николайшорского массива (табл. 1).

Такиим образом, кристаллизация монацита происходила при высоких температурах, а именно от $708^{\circ} \mathrm{C}$ до $784^{\circ} \mathrm{C}$. Кроме того, согласно последовательности кристаллизации минералов, которую для рассматриваемого массива определили М.В. Фишман и его коллеги (Фишман, 1968), николайшорский монацит выделялся на заключительной стадии формировании гранитов изученного массива. Это не соответствует предположению В.П. Водолазской (Водолазская и др., 1997) о низкотемпературном характере рассматриваемых пород.

\section{Заключение}

Полученные результаты, основанные на использовании монацита в качестве геотермометра ,позволяют сделать вывод, что граниты Николайшорского массива являются высокотемпературными образованиями, причем завершающая стадия формирования пород изученного массива проходила при температурах от $708^{\circ} \mathrm{C}$ до $784^{\circ} \mathrm{C}$.

Это подтверждает более ранние данные автора, согласно которым температурный диапазон образования пород Николайшорского гранитного массива составляет: на основе термометрии насыщения Е.Б. Ватсона по циркону $-606-648^{\circ} \mathrm{C}$, термометрии насыщения Е.Б. Ватсона по апати- 
ту - 650-900 을 эволюционного кристалломорфологического анализа Дж.- П. Пюпена - 634-877 ${ }^{\circ} \mathrm{C}$ (Денисова, 2016, 2018).

Таблица 1. Химический состав гранитов Николайшорского массива.

Table 1. Chemical composition of the Nikolaishor massif granites.

\begin{tabular}{|c|c|c|c|c|c|}
\hline Номер пробы & $\mathrm{H}-1$ & $\mathrm{H}-2$ & $\mathrm{H}-4$ & $\mathrm{H}-5$ & $\mathrm{H}-7$ \\
\hline \multicolumn{6}{|c|}{ Основной компонент, масс. \% } \\
\hline $\mathrm{SiO}_{2}$ & 74.20 & 75.50 & 76.11 & 76.14 & 75.76 \\
\hline $\mathrm{TiO}_{2}$ & 0.13 & 0.16 & 0.05 & 0.10 & 0.10 \\
\hline $\mathrm{Al}_{2} \mathrm{O}_{3}$ & 13.53 & 13.72 & 13.67 & 12.57 & 13.14 \\
\hline $\mathrm{FeO}$ & 0.61 & 0.72 & 1.01 & 0.89 & 0.97 \\
\hline $\mathrm{Fe}_{2} \mathrm{O}_{3}$ & 1.65 & 1.21 & 0.48 & 0.42 & 0.75 \\
\hline $\mathrm{MnO}$ & 0.03 & 0.01 & 0.02 & 0.04 & 0.02 \\
\hline $\mathrm{MgO}$ & 0.05 & 0.30 & 0.35 & 0.18 & 0.42 \\
\hline $\mathrm{CaO}$ & 2.01 & 1.55 & 0.46 & 1.22 & 0.59 \\
\hline $\mathrm{Na}_{2} \mathrm{O}$ & 4.28 & 3.84 & 3.11 & 3.28 & 3.33 \\
\hline $\mathrm{K}_{2} \mathrm{O}$ & 2.53 & 3.53 & 4.89 & 4.31 & 5.14 \\
\hline $\mathrm{P}_{2} \mathrm{O}_{5}$ & 0.04 & 0.01 & 0.01 & 0.02 & 0.02 \\
\hline ПпП & 0.74 & 0.32 & 0.23 & 1.08 & 0.62 \\
\hline$\sum$ & 99.80 & 100.87 & 100.39 & 100.25 & 100.86 \\
\hline \multicolumn{6}{|c|}{ Редкие элементы, г/т } \\
\hline $\mathrm{La}$ & 18.91 & 15.30 & 16.70 & 24.12 & 14.48 \\
\hline $\mathrm{Ce}$ & 28.21 & 22.97 & 33.57 & 43.15 & 21.59 \\
\hline $\operatorname{Pr}$ & 3.34 & 2.68 & 3.87 & 4.48 & 2.11 \\
\hline $\mathrm{Nd}$ & 9.35 & 7.42 & 11.9 & 14.59 & 6.15 \\
\hline $\mathrm{Sm}$ & 2.25 & 1.84 & 4.79 & 6.69 & 3.59 \\
\hline $\mathrm{Eu}$ & 0.41 & 0.33 & 0.41 & 0.52 & 0.29 \\
\hline $\mathrm{Gd}$ & 2.19 & 1.91 & 2.85 & 3.38 & 1.85 \\
\hline $\mathrm{Tb}$ & 0.39 & 0.32 & 0.49 & 0.59 & 0.28 \\
\hline Dy & 2.42 & 1.92 & 2.88 & 3.68 & 1.73 \\
\hline Ho & 0.53 & 0.39 & 0.63 & 0.77 & 0.35 \\
\hline $\mathrm{Er}$ & 1.54 & 1.14 & 1.64 & 1.92 & 1.05 \\
\hline $\mathrm{Tm}$ & 0.23 & 0.17 & 0.28 & 0.35 & 0.15 \\
\hline $\mathrm{Yb}$ & 1.01 & 0.83 & 1.29 & 1.65 & 0.87 \\
\hline $\mathrm{Lu}$ & 0.20 & 0.15 & 0.28 & 0.33 & 0.17 \\
\hline \multicolumn{6}{|c|}{ Температура, ${ }^{\circ} \mathrm{C}$} \\
\hline $\mathrm{T}^{\mathrm{C}}$ & 718 & 720 & 755 & 785 & 708 \\
\hline
\end{tabular}

Примечание. Химический состав гранитов получен с помощью силикатного метода в ЦКП «Наука» Институте геологии Коми НЦ УрО РАН (Сыктывкар, аналитик О.В. Кокшарова). Содержания редких элементов получены с помощью ICP- MS метода в Институте геологии и геохимии (Екатеринбург, аналитик Ю.Л. Ронкин).

Исследования проведены в рамках НИР ИГ Коми НЦ УрО РАН ГР № АААА-А17-117121270035-0 и при финансовой поддержке Программы фундаментальных исследований РАН № 18-5-5-19.

\section{Литература}

1. Денисова Ю.В. Термометрия циркона из гранитоидов Приполярного Урала // Вестник Института геологии Коми НЦ УрО РАН. Сыктывкар. № 11. 2016. С. 11-22.

2. Денисова Ю.В. Апатит Николайшорского гранитного массива (Приполярный Урал) // Вестник Института геологии Коми НЦ УрО РАН. Сыктывкар. № 9. 2018. С. 24-29. 
3. Водолазская В.П., Котов К.Н., Шергина Ю.П. О возрасте и генезисе гранитоидов Приполярного Урала // Гранитоидные вулкано- плутонические ассоциации: петрология, геодинамика, металлогения. Сыктывкар. Геопринт. 1997. С. 34-36.

4. Пыстин А.М., Пыстина Ю.И. Метаморфизм и гранитообразование в протерозойско- раннепалеозойской истории формирования Приполярноуральского сегмента земной коры // Литосфера. 2008. № 11. С. 25-38.

5. Фишман М.В., Юшкин Н.П., Голдин Б.А., Калинин Е.П. Минералогия, типоморфизм и генезис акцессорных минералов изверженных пород севера Урала и Тимана. М.- Л.: Наука. 1968. 252 с.

6. Chappeil B.W., Whitte A- J. R. Two contrasting granite types // Pacif. Geol. 1974. V. 8. P. 173-174.

7. Montel J.M. A model for monazite/melt equilibrium and application to the generation of granitic magmas // Chem. Geol. V. 110. 1993. P. 127-146.

8. Pupin J.- P. Zircon and granite petrology // Contrib. Miner. Petrol. V. 73. 1980. P. 207-220.

9. Watson E.B., Harrison T.M. Zircon saturation revisited: Temperature and composition effects in a variety of crustal magma types // Earth and Planetary Science Letters. V. 64. 1983. P. 295-304.

10. Watson E.B., Wark D. A., and Thomas J.B. Crystallization thermometers for zircon and rutile // Contributions to Mineralogy and Petrology. V. 151. 2006. P. 413-433. 